\title{
Hypothetical Aspect of Crowdfunding as Alternate Finance for University Spinoffs and Quadruple Helix
}

\author{
Francis Kwaku Kuma ${ }^{1,2,}{ }^{*}$, Mohd Effandi Yosuff ${ }^{1}$
}

${ }^{1}$ Department of Accounting \& Finance, Azman Hashim International Business School, Universiti Teknologi Malaysia, 81310 Johor Bahru, Johor, Malaysia

2 Department of Accountancy, Koforidua Technical University, Koforidua, Ghana

\author{
${ }^{*}$ Corresponding author email: \\ francis.kwaku.kuma@graduate.ut \\ m.my \\ Received date: 5 Feb 2020 \\ Published date: 31 Dec 2020

\section{How to cite:} \\ Kuma, F.K. \& Yosuff, M.E. (2020). \\ Hypothetical Aspect of \\ Crowdfunding as Alternate \\ Finance for University Spinoffs \\ and Quadruple Helix. Journal of \\ Research Management \& \\ Governance, 3(1), 1-17. Retrieved \\ from https://ejournal.um.edu.my/ \\ index.php/JRMG/article/ \\ view/22096
}

DOI:

https://doi.org/10.22452/

jrmg.vol3no1.1

\begin{abstract}
In this study, we address the finance gaps that threaten the operations of University Spinoffs (USOs), by examining the financing options available to sustain their activities. The study thus discusses crowdfunding as alternate finance to address these financial gaps using the quadruple helix model of innovation. The study combines theoretical perspectives of the quadruple helix model with the practical aspects of USOs raising finance using the crowd. We examine the internal and external financing sources for USOs and explain theoretically, why USOs can rely on crowdfunding as alternate finance. The key concepts of the concept are critically considered, and the study is thus conducted in the form of a review of literature and expression of opinion. Accordingly, the empirical justification of the concept presented is not within the scope of this paper.
\end{abstract}

Keywords: Spinoff; Crowdfunding; Quadruple Helix; Alternate Funding; Innovation

\section{Introduction}

In recent years, researchers have investigated a variety of approaches to funding University spinoff (USOs) companies but there is limited research on using crowdfunding as an alternative source of funding USOs and the linkage of that to the Quadruple Helix model of innovation. Our study reviewed the defining literature on current funding streams for USOs and explored crowdfunding as an alternative source because existing research suggests most startup companies struggle to raise fund from the banks and other traditional sources.

Firstly, within this paper we made some theoretical contributions by providing novel insights into the crowdfunding as an alternative financing for USOs and the financial challenges of USOs. Secondly, we explained the theory of Quadruple Helix in the context of commercialization of university technology, which involves industry and end users and their financial contributions to the success of technology commercialization, (Miller et al., 2018). 
The paper commences with an overview of extant literature in the subject area and therefore limited empirical evidence is available specifically on the justification of the theory presented in our study. We also limited our study generally to the field of crowdfunding as an alternate source of finding for USOs and the commercialization of university technology using the Quadruple Helix model.

hared values. A more formal relationship, professional networks, are established through academic and research activities such as contacts known during attendance to conferences, workshops and seminars. On the other hand, interactions with potential customers, suppliers, investors and competitors constitute networks from the business community.

\section{Conceptual Framework}

The study sought to explore factors that influence growth of USOs and to suggest crowdfunding as an alternate finance for USOs. Accordingly, it integrated one main underpinning theory, which is Quadruple Helix Innovative theory to develop the research framework. This theory was chosen because it considers the relationship between the various stakeholders in the quadruple helix and the roles they play in the commercialization of innovation (Miller et al., 2018). The study looked at the concepts of Quadruple Helix model and its relevance to USOs and crowdfunding. The Quadruple Helix model, which is a successor to the Triple Helix model, is centred on the idea of the coming together of government, academia, business and societal based innovation users to foster innovation and economic prosperity as shown in Figure 2 (Kolehmainen et al., 2016). However, the 4th helix, which is community, was a new addition as seen in Figure 1.
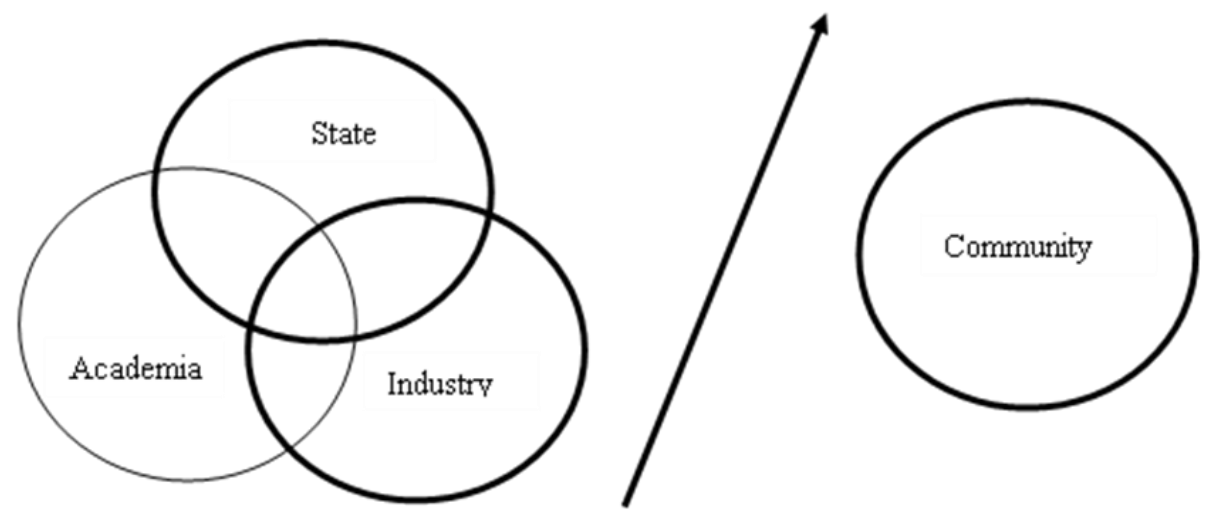

Triple Helix Models of Academia - State - Business Relations

Inclusion of $4^{\text {th }}$ Helix - Community

Figure 1: Triple Helix Models of Academia - State - Business Relations

(Etzkowitz and Leydesdorff, 2000). 


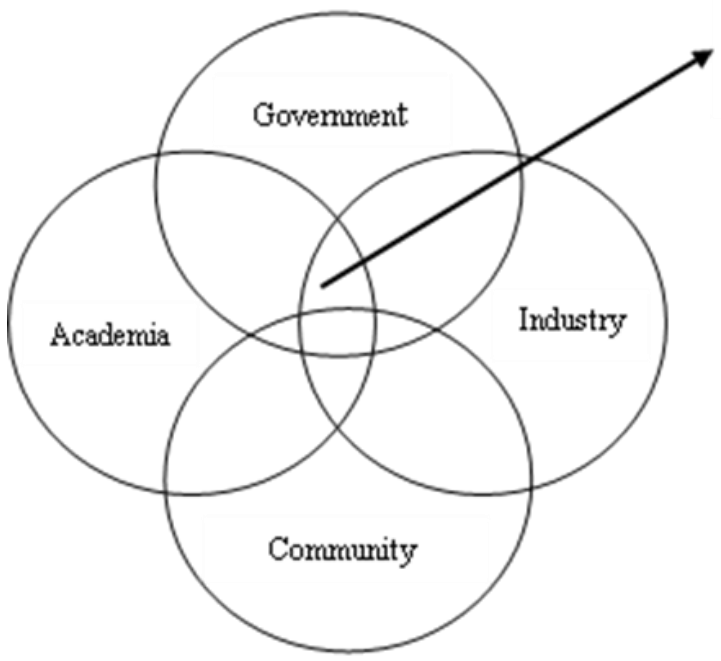

Quadruple Helix Interaction

(Collaborative Innovation)

Figure 2: Quadruple Helix Model of Academia - State - Business- Community Relations (Carayannis et al., 2016).

\subsection{Quadruple Helix Model, Crowdfunding and USOs}

The Quadruple Helix model, adds to the Triple Helix, a fourth helix, which is societal based innovation users (community) and thus, bringing the number of stakeholders in the helix to four (Carayannis et al., 2012; Miller et al., 2018). Interestingly, the concept of crowdfunding is related to the model because innovation involves the interaction between organizations, individuals, communities and the government (Belleflamme et al., 2014). Crowdfunding therefore is a way for USOs to raise funds from unlimited groups of people within the helices to enable them commercializes their innovations as can be seen in Figure 3. The community therefore becomes the source of funding for the other stakeholder in the helix. (Carayannis et al., 2012).

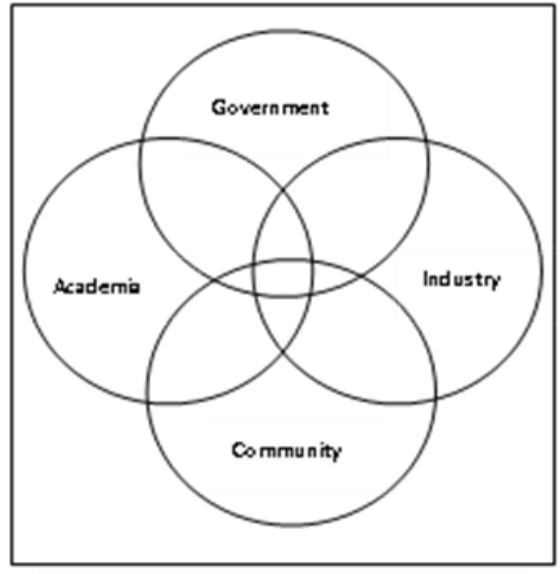

Quadruple Helix Model

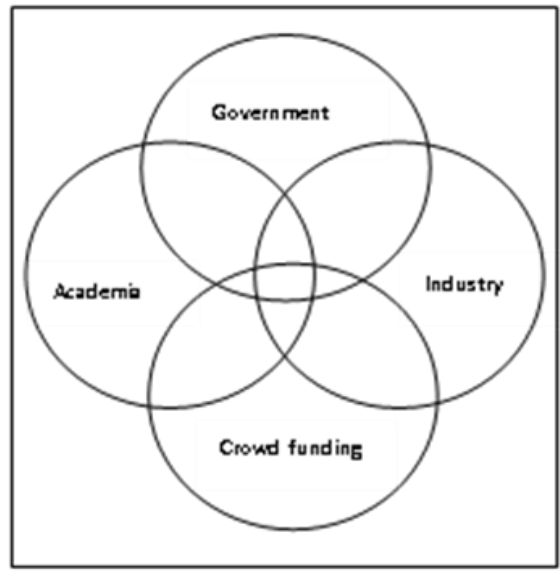

Conceptual Framework

Figure 3: Quadruple Helix Model and the Conceptual Framework

(Carayannis and Campbell, 2019a). 


\subsection{Relationship between Quadruple Helix Innovation theory and USOs}

Consistent with theoretical arguments, our main proposition is that USOs serve as a vital link between the academia and the community, which is another stakeholder in the helix. The academia is capable of establishing USOs which can boost economic growth by creating employment which is knowledge-based and improves the growth capacity of a region, (Clausen and Rasmussen, 2013; Ramaciotti and Rizzo, 2015). Interestingly, other scholars have also pointed out the fact that USOs can help in commercializing research findings that may have not been developed (Miller et al., 2018). Several other researchers have investigated the role of universities in knowledge spillovers from university educational to economic and social development in the form of establishing spinoff companies, which help in the development of a particular region (Dzisah and Etzkowitz, 2008).

\section{University spinoff companies (USOs)}

USOs are vital mechanisms for transmitting knowledge to industry because they are avenues for promoting economic development (Civera et al., 2019; Miller et al., 2018). Essentially they are noted for creating knowledge-based employment and dissemination of new technology to improve the regions in which they are located (Mathisen and Rasmussen, 2019). Existing research thus suggests USOs have the capacity to commercialize underdeveloped research results when they get financial support particularly from the government (helix 4) (Miller et al., 2018; Shane, 2004). The government thus tries to often support USOs created by the academia (helix 1) with the hope of enhancing their capacity to commercialize scientific research (Mathisen and Rasmussen, 2019).

Even though USOs are not a new phenomenon (Etzkowitz and Leydesdorff, 2000), they have gained prominence in the recent times because of their strong economic impact on society (Shane, 2004). For instance, research and technology developed by universities are known to have played pioneering role in firms like Genentech, Lycos and Google (Bonardo et al., 2011). In addition, USOs are greatly involved in the creation of biotech industries. According to Bonardo et al. (2011), about a quarter of all IPOs in hightech industries in Europe are owned by USOs. They explain that USOs in Europe have high shares in most start-up biotech industry, thereby creating high regional impacts. Similarly, Lawton Smith and Ho (2006) indicate that USOs from Oxford University accounts for at least 3.5\% of employment in the local area (Smith and Romeo, 2012).

\subsection{Definition of university spinoff companies}

After setting out a review of the literature on the various definitions of USOs, it has become clear that there is some ambiguities characterising these definitions (Mathisen and Rasmussen, 2019; Sipe, 2012; Yusoff, 2012).

From the perspective of it being an intellectual property and patent for universities and research institutions, Di Gregorio and Shane, (2003) define USOs as "firms that exploit intellectual property or patented inventions generated from university research." Taking it from a viewpoint of technological transfer and focusing on the former employees, Steffensen et al., (2000) define USOs as "a new company that is formed by individuals who were former employees of a parent organization, and a core technology that is transferred from the parent organization." In contrast, Etzkowitz and Klofsten, (2005) 
emphasize on the autonomy and legal identity of USOs by giving describing them as "new business (autonomous entity from the university) with its own legal identity".

Ferri et al., (2019) and Mathisen and Rasmussen, (2019) emphasize on job creation and economic boost by defining USOs as enterprises that "boost economic growth by creating employment which is knowledge-based and also improve tax revenues, through transmission of new technology, while also improving the growth capacity of a region." Wright et al., (2006) describes USOs as enterprises that create wealth and therefore the governments should provide them finance and provide them access to venture capital. According to Wright et al (2006), this is because finance is the main obstacle faced by these companies. They explain that commercialization of university research has become very relevant because it promotes the business growth abilities of technology of the university. It also enhances the resource stocks as well as developing technology capabilities of the universities (Wright et al., 2006).

Table 1: Definition of university spinoffs (USOs).

\begin{tabular}{ll}
\hline \multicolumn{1}{c}{ Author } & \multicolumn{1}{c}{ Definition } \\
\hline $\begin{array}{l}\text { Mathisen and } \\
\text { Rasmussen, }\end{array}$ & $\begin{array}{l}\text { USOs are new ventures commercializing research results and } \\
\text { scientific knowledge from universities and PRIs. }\end{array}$ \\
$\begin{array}{l}\text { Ferri et al., } \\
\text { (2019) }\end{array}$ & $\begin{array}{l}\text { In some industries, such as the biotech industry, USOs repre- } \\
\text { sents a high share of all start-ups. }\end{array}$ \\
$\begin{array}{l}\text { Di Gregorio and } \\
\text { Shane, (2003) }\end{array}$ & $\begin{array}{l}\text { University spinoff ventures are firms that exploit intellectual } \\
\text { property or patented inventions generated from university } \\
\text { research. }\end{array}$ \\
$\begin{array}{l}\text { Steffensen et } \\
\text { al., (2000) }\end{array}$ & $\begin{array}{l}\text { A new company that is formed by individuals who were for- } \\
\text { mer employees of a parent organization, and a core technol- } \\
\text { ogy that is transferred from the parent organization." }\end{array}$ \\
$\begin{array}{l}\text { Wright et al., } \\
\text { (2006) }\end{array}$ & $\begin{array}{l}\text { Enterprises that create wealth and therefore the govern- } \\
\text { ments should provide them finance and also provide them } \\
\text { access to venture capital. }\end{array}$ \\
$\begin{array}{l}\text { Lockett et al., } \\
\text { (2005) }\end{array}$ & $\begin{array}{l}\text { Development of USOs is achieved through pooling together } \\
\text { individuals with matching forms of human capital. }\end{array}$ \\
\hline
\end{tabular}

\section{Funding Streams for University Spinoffs and the Quadruple Helix}

In order to address the challenges in the study, we focus not exclusively on crowdfunding as the main sources of funding for USOs because our aim is to suggest crowdfunding as an alternative funding to USOs. We looked at the different ways USOs could raise funds among the various stakeholders in the helix for their operations including internal funding, loans or debt, equity finance and crowdfunding. 
Countervailing evidence shows that more often than not USOs rely on their own internal sources of fund (helix 1), debt and equity (helix 3) to fund their activities (see Table 2), (Wright et al., 2006). In addition, studies have shown that access to finance is the key success factor for USOs, (Walthoff-Borm et al., 2018; Ko and McKelvie, 2018) because a company's success or failure hinges largely on its initial financing decisions (Ahlers et al., 2015). The study therefore looks at each of these funding in details and then suggests crowdfunding as an alternative source. The study extends this further by investigating the role quadruple helix plays in this concept.

\subsection{USOs' internal funding}

A number of empirical studies suggest that based on the Pecking Order Theory companies first fall on their internal funding before going in for external funding (Bhama et al., 2019; Kuma and Effandi Yosuff, 2020). This is because internal financing is cheaper compared to external (Myers and Majluf, 1984; Vanacker and Manigart, 2010).

To explore this further, we apply the quadruple helix model to our discussions because the academia which is helix 1 in the model plays a vital role in raising fund internally to provide innovation to the community which is helix 4 and a new addition to the model (Carayannis and Campbell, 2019b). The same argument can be put forward for government, helix 2 in the model, which provides subsidy to the universities (Miller et al., 2018) (Figure 2).

Extant research to date, albeit limited suggests that internal fund generated by universities from their research contracts, consultancies and government subsidy forms about $70 \%$ of their initial capital (Carayannis and Campbell, 2019b; Miller et al., 2018; Mustar et al., 2008). They depend on these sources to provide funding for the early stage developments of their startups to provide innovation to societal based users (Wright et al., 2006). Due to this, they lack the financial capacity to sustain their USOs. This is particularly true for USOs in developing economies like ASEAN and African countries (Mensah et al., 2019; Zhang, 2014). USOs in these economies struggle to commercialize their innovations and other research findings because they have limited access to capital (Hoegen et al., 2018). In order to address this challenge, we suggest that these universities need to look for other alternative sources to overcome these financial gaps.

\subsection{Debt finance}

Similarly, applying the quadruple helix we found out that the banks, which provide debt finance to USOs fall within the helix. This is a clear indication of the strong links between the stakeholders on the quadruple helix model and how they are interrelated (Ferri et al., 2019). Extant literature suggests that inadequate funding compels USOs to rely on bank debt as a major source of external funding for their business activities, (Carayannis and Campbell, 2019b; Keasey and Watson, 1994). This is because obtaining debt finance is more flexible, less complicated, and less expensive. Again, USOs' obligations to the banks or lenders are only for the loan-servicing period. After the repayment period, the USOs become completely free from their loan obligation.

However, the challenge is that a high gearing ratio will undeniably affect the credit rating of the USOs and this could result in paying higher interest rate on issued bonds to attract investors because they 
would be measured as risky particularly when they have expressively larger amount of debt than equity financing. The payment of high coupon rate on such bonds would give the USOs future cash flow problems (Hoegen et al., 2018; Keasey and Watson, 1994).

\subsection{Equity finance}

Furthermore, we present the same applications of the quadruple helix model based on the literature reviewed and we found out that equity finance providers fall within the helix. Equity finance providers such as business angels and venture capitalists strongly feature on the model (Carayannis and Campbell, 2019b; Carayannis et al., 2012; McAdam et al., 2016). Equity finance is an external source of finance that the USOs fall on because business angels and venture capitalists provide equity finance by investing in USOs. However, they have challenges in accessing this type of funding because of their inability to convince venture capitalists to buy their shares (Keasey and Watson, 1994). Venture capital firms are noted for detailed scrutiny of USOs proposals (Lockett and Wright, 2005), before investing their money into them. This scrutiny therefore discourages USOs because of the cost involve in their evaluations (Caiazza, 2014).

For instance, a study by Wright et al., (2006) explains that in the early 1990s, venture capital firms in the UK were reluctant to invest in new technology based firms because of the risk associated with such investments. The challenge of accessing equity finance for startups was recognized in Europe years ago; due to this, government funding initiatives were introduced to support new high-tech firms (Clarysse et al., 2007; Wright et al., 2006).

The positive side of equity finance is that it is less risky because of the absence of regular loan repayments. Again, with equity finance, surplus cash is retained in the business and this can be reinvested to enhance the growth of the business.

\subsection{State funding}

Extant literature suggests that USOs depend largely on the state for funding to support their spinoff activities. The state, which is in helix 2 therefore, plays important role in transferring innovation to end users. The assertion is confirmed by a study conducted by Wright et al., (2006) on funding intitiaves provided by the state to the high-tech firms in Europe (Clarysse et al., 2007; Wright et al., 2006). This reaffirmed the claim that the state (helix 2) contributes significantly to the development of USOs particularly in the developed countries (Ayensu et al., 2016; González Cacheda, 2018). 
Table 2: Funding streams for university spinoffs based on Quadruple Helix .

\begin{tabular}{|c|c|c|}
\hline Finance & Literature & $\begin{array}{c}\text { Sources based on Quadruple Helix } \\
\text { Stakeholders }\end{array}$ \\
\hline $\begin{array}{l}\text { Debt } \\
\text { finance }\end{array}$ & $\begin{array}{l}\text { Keasey and Watson (1994), } \\
\text { Vanacker and Manigart } \\
\text { (2010) }\end{array}$ & $\begin{array}{l}\text { Helix } 3 \\
\text { Banks } \\
\text { (Businesses) }\end{array}$ \\
\hline $\begin{array}{l}\text { Equity } \\
\text { finance }\end{array}$ & $\begin{array}{l}\text { Lockett et al., (2005), Mus- } \\
\text { cio et al. (2013) }\end{array}$ & $\begin{array}{l}\text { Helix } 3 \\
\text { Business angels } \\
\text { Venture capitalists } \\
\text { (Businesses) }\end{array}$ \\
\hline $\begin{array}{l}\text { Internal } \\
\text { funds }\end{array}$ & $\begin{array}{l}\text { Mustar et al. (2008), Smilor } \\
\text { et al. (1990) }\end{array}$ & $\begin{array}{l}\text { Helix } 1 \& 2 \\
\text { Universities-Research contracts and } \\
\text { consultancies } \\
\text { Government -subsidy } \\
\text { (Academia\& Govt.) }\end{array}$ \\
\hline $\begin{array}{l}\text { Crowd- } \\
\text { funding }\end{array}$ & $\begin{array}{l}\text { Mollick (2014), Cox and Ngu- } \\
\text { yen (2018) }\end{array}$ & $\begin{array}{l}\text { Helix } 4 \\
\text { Crowd/Platform- } \\
\text { (Societal end-users) }\end{array}$ \\
\hline
\end{tabular}

\section{The Concept of Crowdfunding}

Our study primarily contributes to the existing literature on the broader definition of crowdfunding as a concept and then examines the relationship between this concept and its practical applications to USOs. Although we discuss the definition of the crowdfunding as an alternative source of funding, we also recognize the contributions of the other stakeholders of the Quadruple Helix in providing finance for USOs as illustrated in Table 2 above.

Crowdfunding refers to fund raising activities from a large group of people using online platforms to fund start-up projects (Cumming et al., 2019; Mollick, 2014; Ordanini et al., 2011). This takes the form of an open call (Crosetto and Regner, 2018). One most important thing about crowdfunding is that it is not limited by geographical boundaries, (Agrawal et al., 2011).

There are three main players involved in crowdfunding appeals and these are the project initiators who propose the project or business ventures to be funded (Kaartemo, 2017; Cordova et al., 2015), individuals or group of individuals who back the project or business venture by making financial contributions, and the internet platforms, which launch the project or business venture (Vismara, 2016). While the study recognizes that crowdfund can serve as an alternative source of funding, perhaps even more of concern is that lack of information between project initiators and backers can result in the project's inability to meet the project goal (Belleflamme et al., 2014). 


\subsection{Definition of Crowdfunding}

The overall evidence emerging from literature suggests that there are variations in the definitions of crowdfunding among scholars. The study therefore presented the following prevailing definitions (Cumming et al., 2019; Block et al., 2018; Belleflamme et al., 2014; Mollick, 2014).

Taking it from the perspective of making appeal to backers for a donation in return for a reward (rewardbased), according to Belleflamme et al. (2014), "Crowdfunding involves an open call, mostly through the Internet, for the provision of financial resources...." Steinberg and DeMaria (2012) on the other hand, placed emphasis on crowdfunding as an alternate funding for new ventures by defining crowdfunding as "the process of asking the general public for donations that provide start-up capital for new ventures."

Viewing it from a different angle and contrasting Belleflamme et al. (2014) and Stenberg et al. (2012) definition, Wheat et al. (2013) saw crowdfunding as a possible avenue for individuals to raise start-up capital by defining it as "A new internet-based method of fundraising in which individuals solicit contributions for projects on specialized crowdfunding websites" (p.1). Mollick (2014) expanded the definition of crowdfunding by placing emphasis on how minimal contributions from a large number of people could constitute a substantial capital for start-ups. He defined crowdfunding as "The efforts by entrepreneurial individuals and groups - cultural, social, and for-profit - to fund their ventures by drawing on relatively small contributions from a relatively large number of individuals using the internet, without standard financial intermediaries."

\subsection{Crowdfunding Platform}

A striking feature of crowdfunding is the platforms, which are the mediums that help to bring all the three parties together (Mollick, 2014). Individuals or backers making financial contributions normally select and support projects that attract their interest. These could be social projects or business ventures. The backers would donate to these social projects in the form of supporting a good course for altruistic purposes (Moon and Hwang, 2018). In the case of business ventures, the backers would buy shares in the venture for capital gains purposes or for dividend purposes. Raising funds from the crowd has very little restriction in the sense that unlike the more traditional sources like the banks and equity finance (Ahlers et al., 2015), smaller amounts of money can be paid by the crowd during a call for crowdfunding appeals. The crowd plays an important role because they provide the needed funds and they act as an alternate source of finance for projects or business ventures (Cumming et al., 2019).

Any business who wants to raise a fund from the crowd will first have to approach crowd funding platform owners (Kraus et al., 2016). The owners will sign a contract with the initiator and then place their projects or ventures on their platform (Belleflamme et al., 2014). They would then launch a campaign by advertising the project to the public (Kuppuswamy and Bayus, 2013). Because the campaign is done online, it attracts funders from across the globe (A. Agrawal et al., 2015) . For instance, a campaign for a project in Ghana or Malaysia can get backers from the USA or Europe. 


\subsection{Types of Crowdfunding Platforms}

The study focused on two main types of crowdfunding platforms in support of its attempts in suggesting crowdfunding as an alternate source of funding for USOs. The platforms are the Reward-based and Equity based platforms.

Reward-based platforms: Existing research thus suggests that empirical research on reward-based crowdfunding emphases on the effects of contribution dynamics of projects, social capital, founder quality, linguistics, and gender. Regarding dynamics of reward-based crowdfunding, Kuppuswamy and Bayus (2013) argue that over a time, contributions from backers for a project shows a u-shaped pattern instead of a non-linear one. This is because the early and later stages of a project's live time attract more funding from funders (Kuppuswamy and Bayus, 2013). The findings of Kuppuswamy and Bayus, (2013) are similar for the various categories of projects, regardless of size or objectives goals or the success story. They attributed the pattern formation to the role played by family and friends in the early and final days of projects (Cumming and Hornuf, 2018; Kuppuswamy and Bayus, 2013).

Furthermore, touching on herding behaviour, they are of the view that funders are influenced by the amount of money raised during a particular funding campaign. Herding therefore plays a vital role in funding campaigns (Kuppuswamy and Bayus, 2013). This is because projects which can generate higher figures from backers outside social media and other institutions are likely to be fully funded (Mollick, 2014). Qiu, (2013) found support for this argument by saying that projects, which featured prominently on the homepages of crowdfunding platforms, receive greater contributions from backers. Mollick (2014) on the other hand, pointed out that funding success is determined by social network size. The two most popular reward-based crowdfunding platforms are Kickstarter and Indiegogo.

Equity based platforms: Due to the unique nature of equity-based crowdfunding, fund raising is conducted on platforms designed for that purpose. These platforms are regulated by laws in most countries with the exception of some African countries where there are no regulations or lack of regulation clarities to govern them (Hiller, 2017).

A number of empirical studies find support for the fact that there is limited research on equity crowdfunding (Hemer, 2011; Mollick, 2014). The lack of adequate research on equity crowdfunding is due to the fact that it is an evolving concept, which has many legal constraints in some countries (Hiller, 2017; Mollick, 2014). Distinctive from previous research that focuses on other aspects of equity crowdfunding Ahlers et al. (2015) explores the significance of signals in equity-based crowdfunding. Accordingly, they concluded that signals about quality of start-ups and uncertainty levels, relate positively to their funding success. Ahlers et al. (2015) focus specially on the parts played by the worth of equity on offer, viz., human capital and financial forecast in increasing the chances of raising adequate funding. In contrast, intellectual capital and social capital has no relation to funding success of start-ups (Hiller, 2017). The two most popular equity based crowdfunding platforms are Crowdcube and AngelList.

\section{Crowdfunding as an Alternative Finance and the Quadruple Helix}

To explore our argument further, we begin by focusing on the role of societal based innovation users (community), i.e., helix 4, which is a new addition to the helix in providing an alternate source of funding 
to USOs (Figure 2). The community (helix 4) constitutes the crowd that could provide funding for USOs to commercialize their innovations. To support this assertion, our study advances the current literature on crowd funding as another source of funding for USOs. Studies suggest that peer-to-peer and equity crowdfunding has expanded rapidly in recent times. Scholars have attributed this phenomenon to the fall on interest rates on savings. Individuals would therefore rather contribute as lenders in peer-to-peer debt crowdfunding market rather than save their money at the banks. Again, some individuals would rather prefer lending money to companies through peer-to-business on crowd funding platforms than save it in the bank (Cox and Nguyen, 2018). Peer-to-peer lending which is an uncollateralized loan for profit purposes is well established in most developed economies and is gaining recognition in developing economies like the ASEAN countries as well (Duarte et al., 2012).

Crowdfunding platforms can therefore provide USOs the access to investors who could invest in the early stages of their business. Comparatively, the threshold amounts for investment on crowdfunding platforms are low, so ordinary investors can be part of the process. More importantly, these investors do not have any control of the business and the servicing costs is quite low (Cumming and Groh, 2018; Vanacker and Manigart, 2010). Again, studies have shown that a quarter of crowdfunding projects do deliver on time and reward-based crowdfunding support USOs, (Block et al., 2018). Finally, empirical research shows that start-ups that are more innovative tend to attract greater interest from crowd investors (Schwienbacher, 2019).

\section{Challenges of Spinoffs}

A study conducted by Oliveira et al. (2018) and Beraza-Garmendia and Rodríguez-Castellanos (2015) suggests that the positive effects of the spin-offs on society is contingent on the growth and ability of the USOs to perform creditably. They further explained that the growth and performance of USOs is therefore not automatic because there are certain factors that affect the growth process.

Other scholars argued that USOs are mostly small firms, which are not significance and have growth challenges and a limited economic impact (Rodeiro-pazos et al., 2017). Therefore, there is no justification for the support they receive from the public, (Ferri et al., 2019). These divergent views according to scholars show a complete misunderstanding of the growth, advancement, and eventual performance of USOs.

Again, another study by Berbegal-Mirabent et al. (2015) explains that there is a limited research on the effects on the performance generated by the incorporation of knowledge transferred by the parent university in the USOs business process. Availability of financial resources can therefore help in the creation processes of USOs. The availability of these resources varies from country to country. For instance, while the state (helix 2) provides adequate funding support for USOs in Europe and the America (Hoegen et al., 2018), there is lack of support for USOs in most African and Asian countries (Aryeetey, 2005). USOs in these developing economies experience static growth compared to their counterparts in the developed economies (Mathisen and Rasmussen, 2019; Mustar et al., 2008).

In recent times, one of the greatest challenges faced by USOs is the capacity to provide state of the arts technology that the market needs. With the emergence of artificial intelligence and other high-tech 
technology, the USOs struggle to meet the needs of the industries as well as innovation end users (Cordova et al., 2015; Kaartemo, 2017). This therefore affects their ability to compete favourably on an already saturated market. They hence become unattractive to business angels and the venture capitalists who are risk averse (Cordova et al., 2015).

Table 3: Challenges of spinoff companies.

\begin{tabular}{ll}
\hline \multicolumn{1}{c}{ Challenges } & \multicolumn{1}{c}{ Literature } \\
\hline $\begin{array}{l}\text { Skills and } \\
\text { networks }\end{array}$ & (Tengeh and Rorwana, 2017) (Vanacker and Manigart, 2010) \\
Future research & (Leyden and Link, 2015) \\
$\begin{array}{l}\text { Inventor } \\
\text { involvement }\end{array}$ & $\begin{array}{l}\text { (Beraza-Garmendia and Rodríguez-Castellanos, 2015), } \\
\text { (Rassenfosse and Fischer, 2016) }\end{array}$ \\
$\begin{array}{l}\text { Team } \\
\text { development }\end{array}$ & (Markman et al., 2016) \\
\hline
\end{tabular}

\section{Success Stories of Crowdfunding}

Even though there is limited information on the contributions of crowdfunding to the growth of USOs, there is ample evidence to suggest that it has contributed immensely to the growth of start-up businesses (Ko and McKelvie, 2018). The following are the success stories of how crowdfunding platforms have helped startups to capitals for their business ventures.

For instance, AngelList, a US-based equity based crowdfunding platform was formed in 2010. It was initially established as social network, which connects start-ups with business angels and job seekers; it has been able to assist start-ups raise $\$ 450$ million in equity funding since its inception (www.angel.com). Again, Crowdcube which is a leading UK equity crowdfunding platform funded in 2011, has over 225,000 investors raising $£ 115$ million on the platform (Walthoff-Borm et al., 2018; Vismara, 2016). Furthermore, Funding Circle which is another UK based peer-to-peer crowdfunding platform that was funded in 2010 permits investors to lend out money directly to start-ups as well as medium size firms (Mateescu, 2015). The platform has about 71,000 retail investors, banks, financial institutions as well as the UK government (Forbes and Schaefer, 2017). Funding Circle platform is estimated to have given out about $\$ 5$ billion loans to 40,000 businesses worldwide. The loans offered by Funding Circle ranges from $\$ 25,000$ to $\$ 500,000$ payable within 5years (www.fundingcircle.com).

Finally, Kickstarter is a USA based reward based crowdfunding platform, which was founded in 2009. The first project that was launched on the platform was known as Drawing for Dollars project launched by a New York based artist known as L.J. Ruell. His target was to raise $\$ 20$ for his art project but he ended up raising \$35 from three backers. L.J. Ruell is thus credited with being the first project launched on Kickstarter (www.kickstarter.com). In addition, the platform successfully launched a project known as the Coolest Cooler created by Ryan Grepper (an American product developer) which was able to raise 
$\$ 13.8$ million. It became the most funded project on Kickstarter in 2014. The coolest cooler is a multifunction cooler, which can store up to 60 drinks that be kept cold for 5 days.

\section{Conclusion}

As far as we know, our study is the first to conceptually integrate quadruple helix, crowdfunding and USOs in a team of stakeholders working together to harness and commercialize innovation. Our paper therefore enhances the academic debate on the coming together of government, business, academia, and societal based innovation users to foster innovation and economic prosperity.

After critically reviewing the role of the community (crowd) in providing funding to USOs to commercialize their innovations, we conclude that there is the need for closer partnership between the stakeholders in the quadruple helix to commercialize innovation. We therefore propose a research agenda that will enhance the practical and theoretical concepts of the financing gaps facing USOs. We are also of the view that there is a need for a clear-cut alternate funding for USOs to address these gaps. Overall, based on evidence emerging from the literature, we propose that USOs should rather adopt crowdfunding as an alternative finance in order to avoid their current disjointed funding streams.

\section{References:}

Agrawal, A., Catalini, C. \& Goldfarb, A. (2015). Crowdfunding: Geography, Social Networks, and the Timing of Investment Decisions. Journal of Economics \& Management Strategy, 24(2, SI), 253274. https://doi.org/10.1111/jems.12093

Agrawal, A.K., Catalini, C. \& Goldfarb, A. (2011). The Geography of Crowdfunding. Cambridge, USA: National Bureau of Economic Research. Retrieved from https://www.nber.org/papers/w16820

Ahlers, G.K.C., Cumming, D., Günther, C. \& Schweizer, D. (2015). Signaling in Equity Crowdfunding. Entrepreneurship: Theory and Practice, 39(4), 955-980. https://doi.org/10.1111/etap.12157

Aryeetey, E. (2005). Informal Finance for Private Sector Development in Sub-Saharan Africa. Journal of Microfinance / ESR Review, 7(1), 3.

Ayensu, F., Gbemu, F.R., Kuma, F.K., Kwesi, M. \& Appiah, O. (2016). High Interest Rate in Ghana: An Empirical Study of Societe Generale Ghana [SG-GH]. IOSR Journal of Economics and Finance, 7(6), 2321-5933. https://doi.org/10.9790/5933-0706037885

Belleflamme, P., Lambert, T. \& Schwienbacher, A. (2014). Crowdfunding: Tapping the right crowd. Journal of Business Venturing, 29(5), 585-609. https://doi.org/10.1016/j.jbusvent.2013.07.003

Beraza-Garmendia, J.M. \& Rodríguez-Castellanos, A. (2015). Characteristics and effectiveness of university spin-off support programmes. Academia Revista Latinoamericana de Administración, 28(1), 14-44. https://doi.org/10.1108/ARLA-09-2013-0139

Berbegal-Mirabent, J., Ribeiro-Soriano, D.E. \& Sánchez García, J.L. (2015). Can a magic recipe foster university spin-off creation? Journal of Business Research, 68(11), 2272-2278. https:// doi.org/10.1016/j.jbusres.2015.06.010

Bhama, V., Jain, P.K. \& Yadav, S.S. (2019). Pecking Order Test at Varying Debt Levels: A Comparative Study of Indian and Chinese Firms. Journal of Emerging Market Finance, 18(2), 237-261. https:// doi.org/10.1177/0972652719846317

Block, J., Hornuf, L. \& Moritz, A. (2018). Which updates during an equity crowdfunding campaign increase crowd participation? Small Business Economics, 50(1), 3-27. https://doi.org/10.1007/ s11187-017-9876-4

Bonardo, D., Paleari, S. \& Vismara, S. (2011). Valuing university-based firms: The effects of academic affiliation on IPO performance. Entrepreneurship: Theory and Practice, 35(4), 755-776. https:// 
doi.org/10.1111/j.1540-6520.2010.00369.x

Caiazza, R. (2014). Factors affecting spin-off creation: Macro, meso and micro level analysis. Journal of Enterprising Communities, 8(2), 103-110. https://doi.org/10.1108/JEC-12-2012-0061

Carayannis, E.G., Campbell, D.F. \& Rehman, S.S. (2016). Mode 3 knowledge production: systems and systems theory, clusters and networks. Journal of Innovation and Entrepreneurship, 5:17. https:// doi.org/10.1186/s13731-016-0045-9

Carayannis, E.G. \& Campbell, D.F.J. (2019a). Innovation Systems in Conceptual Evolution: Mode 3 Knowledge Production in Quadruple and Quintuple Helix Innovation Systems, pp. 39-49. In: Smart Quintuple Helix Innovation Systems. SpringerBriefs in Business. Springer, Cham. https:// doi.org/10.1007/978-3-030-01517-6_5

Carayannis, E.G. \& Campbell, D.F.J. (2019b). Mode 1, Mode 2, and Mode 3: Triple Helix and Quadruple Helix, pp. 17.30. In: Smart Quintuple Helix Innovation Systems. SpringerBriefs in Business. Springer, Cham. https://doi.org/10.1007/978-3-030-01517-6_3

Carayannis, E.G., Barth, T.D. \& Campbell, D.F. (2012). The Quintuple Helix innovation model: global warming as a challenge and driver for innovation. Journal of Innovation and Entrepreneurship, 1 (2). https://doi.org/10.1186/2192-5372-1-2

Clarysse, B., Wright, M., Lockett, A., Mustar, P. \& Knockaert, M. (2007). Academic spin-offs, formal technology transfer and capital raising. Industrial and Corporate Change, 16(4), 609-640. https:// doi.org/10.1093/icc/dtm019

Civera, A., Donina, D., Meoli, M. \& Vismara, S. (2019). Fostering the creation of academic spinoffs: does the international mobility of the academic leader matter? International Entrepreneurship and Management Journal, 16, 439-465. https://doi.org/10.1007/s11365-019-00559-8

Clausen, T.H. \& Rasmussen, E. (2013). Parallel business models and the innovativeness of research-based spin-off ventures. Journal of Technology Transfer, 38(6), 836-849. https://doi.org/10.1007/ s10961-012-9294-3

Cordova, A., Dolci, J. \& Gianfrate, G. (2015). The Determinants of Crowdfunding Success: Evidence from Technology Projects. Procedia - Social and Behavioral Sciences, 181, 115-124. https:// doi.org/10.1016/j.sbspro.2015.04.872

Cox, J. \& Nguyen, T. (2018). Does the crowd mean business? An analysis of rewards-based crowdfunding as a source of finance for start-ups and small businesses. Journal of Small Business and Enterprise Development, 25(1), 147-162. https://doi.org/10.1108/JSBED-05-2017-0165

Crosetto, P. \& Regner, T. (2018). It's never too late: Funding dynamics and self pledges in reward-based crowdfunding. Research Policy, 47(8), 1463-1477. https://doi.org/10.1016/j.respol.2018.04.020

Cumming, D. \& Groh, A.P. (2018). Entrepreneurial finance: Unifying themes and future directions. Journal of Corporate Finance, 50, 538-555. https://doi.org/10.1016/j.jcorpfin.2018.01.011

Cumming, D. \& Hornuf, L. (2018). The Economics of Crowdfunding: Startups, Portals and Investor Behavior. Palgrave Macmillan, Cham. https://doi.org/10.1007/978-3-319-66119-3

Cumming, D.J., Leboeuf, G. \& Schwienbacher, A. (2019). Crowdfunding models: Keep-lt-All vs. All-OrNothing. Financial Management, 49(2), 1-41. https://doi.org/10.1111/fima.12262

Di Gregorio, D. \& Shane, S. (2003). Why do some universities generate more start-ups than others? Research Policy, 32(2 SPEC.), 209-227. https://doi.org/10.1016/S0048-7333(02)00097-5

Duarte, J., Siegel, S., Young, L. \& Foster, M.G. (2012). Trust and Credit : The Role of Appearance in Peerto-peer Lending. The Review of Financial Studies, 25(8), 2455-2484. https://doi.org/10.1093/rfs/ hhs071

Dzisah, J. \& Etzkowitz, H. (2008). Triple helix circulation: the heart of innovation and development. International Journal of Technology Management and Sustainable Development, 7(2), 101-115. https://doi.org/10.1386/ijtm.7.2.101_1

Etzkowitz, H. \& Klofsten, M. (2005). The innovating region: Toward a theory of knowledge-based regional 
development. $R$ and $D$ Management, 35(3), 243-255. https://doi.org/10.1111/j.14679310.2005.00387.x

Etzkowitz, H. \& Leydesdorff, L. (2000). The dynamics of innovation: From National Systems and "mode 2" to a Triple Helix of university-industry-government relations. Research Policy, 29(2), 109-123. https://doi.org/10.1016/S0048-7333(99)00055-4

Ferri, S., Fiorentino, R., Parmentola, A. \& Sapio, A. (2019). Patenting or not? The dilemma of academic spin-off founders. Business Process Management Journal, 25(1), 84-103. https://doi.org/10.1108/ BPMJ-06-2017-0163

Forbes, H. \& Schaefer, D. (2017). Guidelines for Successful Crowdfunding. Procedia CIRP, 60, 398-403. https://doi.org/10.1016/j.procir.2017.02.021

González Cacheda, B. (2018). Social Innovation and Crisis in the Third Sector in Spain. Results, Challenges and Limitations of 'Civic Crowdfunding.' Journal of Civil Society, 14(4), 275-291. https:// doi.org/10.1080/17448689.2018.1459239

Hemer, J. (2011). A snapshot on crowdfunding, Arbeitspapiere Unternehmen und Region, No. R2/2011, Fraunhofer ISI, Karlsruhe. Retrieved from https://www.econstor.eu/ bitstream/10419/52302/1/671522264.pdf

Hiller, A. (2017). An Empirical Analysis of Crowdfunding in Sub-Saharan Africa. 209.

Hoegen, A., Steininger, D.M. \& Veit, D. (2018). How do investors decide? An interdisciplinary review of decision-making in crowdfunding. Electronic Markets, 28(3), 339-365. https://doi.org/10.1007/ s12525-017-0269-y

Kaartemo, V. (2017). The Elements of a Successful Crowdfunding Campaign: A Systematic Literature Review of Crowdfunding Performance. International Review of Entrepreneurship, 15(3).

Keasey, K. \& Watson, R. (1994). The bank financing of small firms in UK: Issues and evidence. Small Business Economics, 6, 349-362. https://doi.org/10.1007/BF01065138

Ko, E.J. \& McKelvie, A. (2018). Signaling for more money: The roles of founders' human capital and investor prominence in resource acquisition across different stages of firm development. Journal of Business Venturing, 33(4), 438-454. https://doi.org/10.1016/j.jbusvent.2018.03.001

Kolehmainen, J., Irvine, J., Stewart, L., Karacsonyi, Z., Szabó, T., Alarinta, J. \& Norberg, A. (2016). Quadruple Helix, Innovation and the Knowledge-Based Development: Lessons from Remote, Rural and Less-Favoured Regions. Journal of the Knowledge Economy, 7(1), 23-42. https:// doi.org/10.1007/s13132-015-0289-9

Kraus, S., Richter, C., Brem, A., Cheng, C.-F. \& Chang, M.-L. (2016). Strategies for reward-based crowdfunding campaigns. Journal of Innovation \& Knowledge, 1(1), 13-23. https:// doi.org/10.1016/j.jik.2016.01.010

Kuma, F.K. \& Effandi Yosuff, M. (2020). The dynamics of Pecking Order and Agency theories on crowdfunding concept as alternate finance for start-up businesses. International Journal of Technology and Management Research, 5(1), 1-13. https://doi.org/10.47127/ijtmr.v5i1.82

Kuppuswamy, V. \& Bayus, B.L. (2013). Crowdfunding creative ideas: the dynamics of projects backers in kickstarter. SSRN Working Paper Series. Retrieved from https://funginstitute.berkeley.edu/wpcontent/uploads/2013/11/Crowdfunding_Creative_Ideas.pdf

Lawton Smith, H. \& Ho, K. (2006). Measuring the performance of Oxford University, Oxford Brookes University and the government laboratories' spin-off companies. Research Policy, 35(10), 15541568. https://doi.org/10.1016/j.respol.2006.09.022

Leyden, D.P. \& Link, A.N. (2015). Toward a theory of the entrepreneurial process. Small Business Economics, 44(3), 475-484. https://doi.org/10.1007/s11187-014-9606-0

Lockett, A., Siegel, D., Wright, M. \& Ensley, M.D. (2005). The creation of spin-off firms at public research institutions: Managerial and policy implications. Research Policy, 34(7), 981-993. https:// 
doi.org/10.1016/j.respol.2005.05.010

Lockett, A. \& Wright, M. (2005). Resources, capabilities, risk capital and the creation of university spinout companies. Research Policy, 34(7), 1043-1057. https://doi.org/10.1016/j.respol.2005.05.006

Markman, G.D., Russo, M., Lumpkin, G.T., Jennings, P.D.D. \& Mair, J. (2016). Entrepreneurship as a Platform for Pursuing Multiple Goals: A Special Issue on Sustainability, Ethics, and Entrepreneurship. Journal of Management Studies, 53(5), 673-694. https://doi.org/10.1111/ joms.12214

Mateescu, A. (2015). Peer-to-Peer Lending. Data \& Society Research Institute. Retrieved from https:// datasociety.net/pubs/dcr/PeertoPeerLending.pdf

Mathisen, M.T. \& Rasmussen, E. (2019). The development, growth, and performance of university spinoffs: a critical review. Journal of Technology Transfer, 44, 1891-1938. https://doi.org/10.1007/ s10961-018-09714-9

McAdam, M., Miller, K. \& McAdam, R. (2016). Situated regional university incubation: A multi-level stakeholder perspective. Technovation, 50-51, 69-78. https://doi.org/10.1016/ j.technovation.2015.09.002

Mensah, M.S.B., Enu-Kwesi, F. \& Boohene, R. (2019). Challenges of Research Collaboration in Ghana's Knowledge-based Economy. Journal of the Knowledge Economy, 10(1), 186-204. https:// doi.org/10.1007/s13132-017-0450-8

Miller, K., McAdam, R. \& McAdam, M. (2018). A systematic literature review of university technology transfer from a quadruple helix perspective: toward a research agenda. $R$ and $D$ Management, 48 (1), 7-24. https://doi.org/10.1111/radm.12228

Mollick, E. (2014). The dynamics of crowdfunding: An exploratory study. Journal of Business Venturing, 29(1), 1-16. https://doi.org/10.1016/j.jbusvent.2013.06.005

Moon, Y. \& Hwang, J. (2018). Crowdfunding as an alternative means for funding sustainable appropriate technology: Acceptance determinants of backers. Sustainability (Switzerland), 10(5), 1-17. https://doi.org/10.3390/su10051456

Muscio, A., Quaglione, D. \& Vallanti, G. (2013). Does government funding complement or substitute private research funding to universities? Research Policy, 42(1), 63-75. https://doi.org/10.1016/ j.respol.2012.04.010

Mustar, P., Wright, M. \& Clarysse, B. (2008). University spin-off firms: Lessons from ten years of experience in Europe. Science and Public Policy, 35(2), 67-80. https:// doi.org/10.3152/030234208X282862

Myers, S.C. \& Majluf, N.S. (1984). Corporate financing and investment decisions when firms have information that investors do not have. Journal of Financial Economics, 13(2), 187-221. https:// doi.org/10.1016/0304-405X(84)90023-0

Oliveira, P.H.d, Cláudia, A. \& Terence, F. (2018). Innovation practices in small technology-based companies during incubation and post-incubation periods. 15(2), 174-188. https:// doi.org/10.1108/INMR-02-2018-007

Ordanini, A., Miceli, L., Pizzetti, M. \& Parasuraman, A.. (2011). Crowd-funding : transforming customers into investors through innovative service platforms. Journal of Service Management, 22(4), 443470.

Qiu, C. (2013). Issues in Crowdfunding: Theoretical and Empirical Investigation on Kickstarter. SSRN Electronic Journal. https://doi.org/10.2139/ssrn.2345872

Ramaciotti, L. \& Rizzo, U. (2015). The determinants of academic spin-off creation by Italian universities. $R$ and D Management, 45(5), 501-514. https://doi.org/10.1111/radm.12105

Rassenfosse, G.D. \& Fischer, T. (2016). Venture Debt Financing: Determinants of the Lending Decision. Strategic Entrepreneurship Journal, 10(3), 235-256. https://doi.org/10.1002/sej.1220

Rodeiro-pazos, D., Coruña, U., Coruña, A. \& Fernández-lópez, S. (2017). The effectiveness of 
entrepreneurial universities at creating surviving firms An exploratory analysis. 11(3), 339-353. https://doi.org/10.1108/JEC-01-2017-0007

Schwienbacher, A. (2019). Equity crowdfunding : anything to celebrate ? Equity crowdfunding : anything to celebrate ? Venture Capital, 21(1), 65-74. https://doi.org/10.1080/13691066.2018.1559010

Shane, S. (2004). Encouraging university entrepreneurship? The effect of the Bayh-Dole Act on university patenting in the United States. Journal of Business Venturing, 19(1), 127-151. https:// doi.org/10.1016/S0883-9026(02)00114-3

Sipe, C.L. (2012). Toward a Typology of Mentoring, pp. 65-80. In DuBois, D.L. \& Karcher, M.J. (eds), Handbook of Youth Mentoring. SAGE Publications, Inc.https:// doi.org/10.4135/9781412976664.n5

Smilor, R. W., Gibson, D. V. \& Dietrich, G. B. (1990). University spin-out companies: Technology start-ups from UT-Austin. Journal of Business Venturing, 5(1), 63-76. https://doi.org/10.1016/0883-9026 (90)90027-Q

Smith, H.L. \& Romeo, S. (2012). Entrepreneurship and innovation: Oxfordshire's high- tech economy firm survival, growth and innovation. Entrepreneurship, Social Capital and Governance: Directions for the Sustainable Development and Competitiveness of Regions, (May), 27-52. https:// doi.org/10.4337/9781781002841.00007

Steffensen, M., Rogers, E.M. \& Speakman, K. (2000). Spin-offs from research centers at a research university. Journal of Business Venturing, 15(1), 93-111. https://doi.org/10.1016/S0883-9026(98) 00006-8

Steinberg, S. and DeMaria, R. (2012). The Crowdfunding Bible: How to Raise Money for Any Startup, Video Game or Project. READ.ME.

Tengeh, R.K. \& Rorwana, A. (2017). Influence of Spin-off and Private Companies in the process of Technology creation and Transfer at a University of Technology in South Africa. Acta Universitatis Danubius: Oeconomica, 13(3), 139-154. Retrieved from http://0search.ebscohost.com.innopac.wits.ac.za/login.aspx? direct $=$ true \& db=bsu\&AN=124218556\&site=ehost-live \&scope=site

Vanacker, T.R. \& Manigart, S. (2010). Pecking order and debt capacity considerations for high-growth companies seeking financing. Small Business Economics, 35(1), 53-69. https://doi.org/10.1007/ s11187-008-9150-x

Vismara, S. (2016). Equity retention and social network theory in equity crowdfunding. Small Business Economics, 46(4), 579-590. https://doi.org/10.1007/s11187-016-9710-4

Walthoff-Borm, X., Schwienbacher, A. \& Vanacker, T. (2018). Equity crowdfunding: First resort or last resort? Journal of Business Venturing, 33(4), 513-533. https://doi.org/10.1016/ j.jbusvent.2018.04.001

Wheat, R.E., Wang, Y., Byrnes, J.E. \& Ranganathan, J. (2013). Raising money for scientific research through crowdfunding. Trends in Ecology \& Evolution, 28(2), 71-72. https://doi.org/10.1016/ j.tree.2012.11.001

Wright, M., Lockett, A., Clarysse, B. \& Binks, M. (2006). University spin-out companies and venture capital. Research Policy, 35(4), 481-501. https://doi.org/10.1016/j.respol.2006.01.005

Yusoff, M. (2012). Commercialisation of Academic Research an Evaluation of Government and Institutional Support for Commercialisation of Academic Research in Malaysia. A thesis submitted in part fulfilment of the requirements of Nottingham Trent University. Nottingham Trent University, (November).

Zhang, X. (2014). Co-financing Green Development with Crowds -Exploring the potential of Crowdfunding. A presentation prepared for SWITCH Asia webinar series on Green Financing, Sep.12, 2014, World Bank. 